\title{
Fen ve Matematik Branş Öğretmenlerinin Eğitim Araştırmalarına Yönelik
}

Tutumları*

\section{Şeyda GÜL ${ }^{* *}, \quad$ Esra ÖZAY KÖSE ${ }^{* * *}$}

Öz: Bu çalışmanın amacı, fen (biyoloji, fizik, kimya) ve matematik öğretmenlerinin eğitim araştırmalarına yönelik tutumlarını incelemektir. $\mathrm{Bu}$ amaçla veri toplamak için Eğitim Araştırmalarına Yönelik Öğretmen Tutum Ölçeği (EAÖTÖ) kullanılmıştır. Ölçek Erzurum il merkezinde kolay ulaşılabilir örnekleme yöntemi ile belirlenmiş liselerde görev yapan ve fen (biyoloji, fizik, kimya) ve matematik branş öğretmenlerinden oluşan toplam 71 kişilik bir gruba uygulanmıştır. Verilerin SPSS 18.0 istatistik programıyla yapılan analizleri sonucu elde edilen bulgular, öğretmenlerin Eğitim Araştırmalarına Yönelik Öğretmen Tutum Ölçeği (EAÖTÖ)'nde yer alan ifadelere katılımının yüksek düzeyde olduğunu ortaya koymuştur. Bulgular, cinsiyet ve branş değiş̧kenleri açısından incelendiğinde ise tüm değişkenler açısından istatistiksel olarak anlamlı farklılık olmadığı $(\mathrm{p}>0.05)$ ortaya çıkmıştır.

Anahtar Kelimeler: Fen ve matematik öğretmeni, Eğitim araştırmaları, Tutum

\footnotetext{
*Bu çalışmanın bir bölümü UFBMEK 2016 kongresine özet metin olarak sunulmuştur.

** Yrd.Doç.Dr.Atatürk Üniversitesi, Eğitim Fak. Biyoloji Öğretmenliği Bölümü, Erzurum, seydagul@ atauni.edu.tr

**** Doç.Dr.Atatürk Üniversitesi, Eğitim Fak. Biyoloji Öğretmenliği Bölümü, Erzurum, esraozay@ atauni.edu.tr
} 
The Attitudes of Science and Mathematics Teachers towards Educational Researches

Abstract: The aim of this study is to examine the science (biology, physics, and chemistry) and mathematics teachers' attitudes towards education researches. For this aim, the data were collected through "Teachers Attitude Scale towards Educational Research (TASTER)". The sample of the study, which was selected through convenience sampling method, was consisted of 71 science (biology, physics, and chemistry) and mathematics teachers working in secondary schools in Erzurum. The data were analized by SPSS 18.0 program. The findings indicated that the teachers agreed in high score the statements of the Teachers Attitude Scale towards Educational Research (TASTER). The findings also indicated that there was no statistically an important difference ( $>0.05)$ between all variables in terms of gender and field variables.

Keywords: Science and math teacher, educational research, Attitudes 


\section{Giriş}

Dünyayı gözlemlemek ve dünya ile ilgili düşünce geliştirmek için kullanılabilecek en etkili yöntemlerden biri olan bilim, bilmenin yoludur ve bilimsel bilginin gelişimine özgü inanç ve değerleri içerir (Güler ve Akman, 2006). Doğru bilgilere ulaşmak ve ulaştığı bilgilerin toplum yararına kullanılmasını sağlama amacını taşıyan bilimin, birçok işlevi bulunmakla birlikte en önemli rollerinden birisi toplumun gelişimine katkı sağlayıp bilimsel araştırmalar yaparak bu işlevi gerçekleştirmektir (Özden ve Ergin, 2013).

Bilimsel araştırma, toplumu tanımaya, profilini betimlemeye, değişkenlerle ilgili ilişkileri ortaya çıkarmaya çalışan, bir sorunun ortaya çıkmasına yol açan etmenlerle ilgili neden, niçin, nasıl, ne zaman, nerede gibi sorulara cevap veren uğraşlar ve bilimsel bilgi üretme işlevidir (Özdamar, 2003, s:2). Bilimsel araştırmaların en karakteristik özelliklerinden biri, birbirini izleyen bir takım basamaklardan oluşmasıdır (Korkmaz, Şahin ve Yeşil, 2011a). Problemin hissedilmesi ile başlayan araştırma süreci; takip edilecek yöntemlerin belirlenmesini ve gereklerinin yerine getirilmesini, verilerin toplanmasını, verilerin işlenmesini, verilerden yola çıkarak soruna çözüm oluşturacak sonuç ve önerilerin geliştirilmesini, ulaşılan sonuç ve sürecin kayıt altına alınmasını, kısacası var olan probleme yönelik bilimsel araştırma süreçleri kullanılarak probleme çözüm bulunmasını içermektedir (Llewellyn, 2002, Korkmaz vd., 2011a; Yaşar, 2014). Bilimsel araştırmalardaki bilgilerin elde ediliş yönteminden dolayı, sonuçların güvenirliği ve geçerliği yüksektir ve bu bakımdan yapılan araştırma sonuçları önemli bir yere sahiptir (İlhan, Şekerci, Sözbilir ve Yıldırım, 2013). 
Bilimsel araştırmalar araştırma sürecinin daha iyi işlemesi için yapıldığı gibi eğitimöğretim sürecinde de çeşitli amaçlarla kullanılabilir. Bu araştırmalar zamanla ortaya çıkan aksaklıkları gidererek eğitim-öğretimin daha verimli hâle gelmesine katkıda bulunurlar (Korkmaz, vd. 2011a). Bu açıdan, ülkelerin ve toplumun gelişmesinde eğitim ve eğitimin sağlıklı bir şekilde yürütülmesinde özellikle eğitim araştırmalarının önemli bir rol oynadığı söylenebilir. Araştırma becerilerine sahip bireylerin yetiştirilmesinde ise öğretmenler önemli bir yere sahip olduğu söylenilebilir. Zira eğitim sistemi içerisinde soru soran ve sorgulayan bireyleri yetiştirme konusunda en fazla sorumluluk sahibi olan kişilerden biri de öğretmenlerdir (Çakmak, Taşkıran ve Bulut, 2015). Dolayısıyla, öğretmenlerden araştırma becerileriyle donatılmış araştırma yapan bireyler olmaları beklenir (Çakmak vd., 2015; Yavuz-Konokman, Tanrıseven ve Karasolak, 2013).

Öğretmenlerin değişen yaşam şartlarına uyum sağlayabilmeleri, araştırma bilgi ve becerilerine sahip olmalarını; yapılan araştırmalara düşünce ve eylemleri ile katkı sağlamalarını; araştırmalara ve araştırmacılara karşı olumlu bir tutum sergileyebilmelerini gerektirir (Biçer, Bozkırlı ve Er, 2013; Korkmaz, vd. 2011a). Bununla beraber öğretmenlerin kendilerinden beklenen yeterliklere sahip olmaları, bu yeterliklere uygun bir şekilde araştırmacı kimliğine bürünmeleri ve mevcut eğitim araştırmalarını kullanmalarının mesleki bilgi, beceri ve deneyimlerine olumlu yönde katkı sağlayacağı bilinmektedir (Çepni, Küçük ve Gökdere, 2002). Ancak, yapılan birçok araştırmada öğretmenlerin genel olarak eğitim araştırmalarından uzak olduğu (İlhan vd., 2013; Küçük, 2002), çoğunlukla araştırmaların veri toplama aşamasında yer aldıkları (De Jong, 2004), mevcut eğitim çalışmalarından gereği kadar faydalanmadıkları (Aydın, Şahin ve Topal, 2008; İlhan vd., 2013), yeteri kadar araştırma yapmadıkları ve mevcut 
araştırmalara karşı bazı olumsuz tutumlara sahip oldukları vurgulanmıştır (Costa, Marques ve Kempa, 2000; Sarı, 2006; Yavuz-Konokman, Tanrıseven ve Karasolak 2013). Bu konu ile ilgili olarak Korkmaz, Şahin ve Yeşil (2011b), öğretmenlerin bilimsel araştırmalara ve araştırmacılara ilişkin düşüncelerini ortaya koymak amacıyla yapmış oldukları çalışmalarında; öğretmenlerin önemli bir bölümü bilimsel araştırmanın gerçekleştirilme süreci hakkında kendilerini yeterli görürken kayda değer bir kısmının ise yeterli görmediği sonucuna ulaşmışlardır. Ayrıca, önemli bir bölümü bilimsel bir araştırmada verilerin toplanması sürecinde katılımcıların zorluk çıkarması, hedef kitleye ulaşamama gibi sorunlar olduğuna, önemli bir bölümü ise veri toplama araçlarına verilen cevapların sübjektif, samimiyetsiz veya gayri ciddi olduğunu ifade etmişlerdir. Bunun yanında öğretmenlerin önemli bir bölümünün ise bilimsel araştırmalara olumlu yaklaştığı ve araştırmacılara yardımcı olmaya çalıştığı, buna karşın bir kısmının olumsuz yaklaştı̆̆ ortaya çıkmıştır.

Küçükoğlu, Taşgın ve Çelik (2014) öğretmen adaylarının bilimsel araştırma sürecine ilişkin görüşlerini incelemek amacıyla yapılan çalışmanın bulgularına göre bilimsel araştırma sürecine ilişkin kavramların öğretmen adayları tarafından tam ve doğru olarak algılanamadığı, öğretmen adaylarının öğretmenlerin araştırma yapmalarının gerekli olduğunu düşünmedikleri, buna karşın bilimsel araştırmaların meslek hayatlarında işlerine yarayacağını düşündükleri belirlenmiştir. Benzer şekilde Biçer vd. (2013) de yapmış oldukları çalışmalarında adayların bilimsel araştırmaya yönelik tutumlarında “Araştırmalara Yönelik Olumsuz Tutum” ve “Araştırmacılara Yönelik Olumlu Tutum” alt boyutlarında anlamlı farklılık olduğu görülmüştür. Ayrıca 4. Sınıfların bilimsel araştırmalara yönelik tutumlarının diğer sınıf düzeylerine göre daha olumsuz olduğu saptanmıştır. 
Kart ve Gelbal (2014), öğretmen adaylarının bilimsel araştırma becerilerine ilişkin öz yeterlik algıları üzerinde etkili olduğu düşünülen faktörleri, ikili karşılaştırmalar kanunuyla ölçekleyerek belirlemeye çalışmışlardır. Elde edilen bulgulara göre, bilimsel araştırma becerilerine ilişkin öğretmen adaylarının; öz yeterlik algılarının veri toplama ve raporlaştırma uyarıcılarının en yüksek yeterlik düzeyine sahip olduğu ancak veri analizi ve değişkenleri belirleme uyarıcılarının ise en düşük yeterliğe sahip olduğu sonucuna ulaşılmıştır.

Çakmak, vd. (2015)'un yaptığı çalışmada ise sosyal bilgiler öğretmen adaylarının bilimsel araştırmaya yönelik tutumları incelenmiştir. Araştırma sonucunda sosyal bilgiler öğretmen adaylarının genel olarak bilimsel araştırmaya yönelik tutumlarının iyi olduğu görülmüştür. Cinsiyet ve sınıf değişkenine göre ölçeğin dört alt boyutunda istatistiksel olarak anlamlı farklılığa rastlanamamıştır; ancak sosyal bilgiler alanında bilimsel yayın okuma sıklığı değişkenine göre ölçeğin araştırmaya yönelik olumlu tutum boyutunda anlamlı farklılıklar olduğu gözlenmiştir.

Alan yazında, yukarıda sıralanan çalı̧̧malara benzer veya farklı nitelikte birçok çalı̧̧manın bulguları genel olarak değerlendirildiğinde, çalışmaların büyük bir çoğunluğunun bilimsel araştırmalara yönelik olduğu, eğitim araştırmalarına yönelik oldukça sınırlı çalışmanın yapıldığı görülmektedir. Bunun yanında, seçilen örneklemin genel olarak sözel ağırlıklı bölümlerdeki branş öğretmenleri ile veya genel olarak tüm alanlardaki öğretmenlerle yürütüldüğü görülmektedir. Ayrıca, araştırma açısından bulgular değerlendirildiğinde, okullarda yürütülen araştırmalar kapsamında kullanılan özellikle anket, ölçek, görüşme, gözlem vb. veri toplama süreçlerine öğretmenler tarafından sıcak bakılmaması ve birçok öğretmenin çeşitli gerekçelerle bu araştırmalara katılmak istememesi, araştırmacılar tarafından sık sık dile getirilen bir sorun 
olarak karşımıza çıkmaktadır (Alber \& Nelson, 2002; Babkie \& Provost, 2004; McBee, 2004; Sarı, 2006). Konuyla ilgili alan yazın incelendiğinde tartışmaların iki yönde ilerlediği görülmektedir: Üniversitelerdeki araştırmacılar, öğretmenlerin öğretim uygulamalarıyla ilgili yapılan araştırmalar hakkında bilgi edinmek için girişimde bulunmadıklarını savunmakta iken, öğretmenler de araştırmacıların ortaya koydukları bilgilerin eğitim ortamlarına doyurucu bir şekilde transfer edilmediğini vurgulamaktadırlar (Sarı, 2006). Savunulan görüş hangi yönde olursa olsun, öğretmenlerin bir bilimsel araştırma/eğitim araştırma kültürüyle yetişmiş olmalarının ve bu kültürü meslek yaşamlarında da başarıyla yaşamaları ve yaşatmalarının taşıdığı önem tartışma götürmez bir gereklilik olarak kabul görmüştür (Sarı, 2006). Bunun yanında eğitim alanında son zamanlarda ortaya çıkan yaklaşımlar, öğretmenlere, mevcut öğretim programlarını uygulama görevinin yanında; araştırma, planlama ve değerlendirme çalışmaları yapma gibi sorumluluklar da yüklemesi nedeniyle öğretmenlerin araştırmacı bir yaklaşıma sahip olmaları, sınıflarında yeni yöntem ve teknikler kullanmaları, bu süreçte karşılaştıkları problemleri çözmeleri ve eğitim araştırmalarına yönelik olumlu tutum geliştirmeleri oldukça önemlidir (Çepni ve Küçük, 2003). Dolayısıyla, eğitimin kalitesini arttırmak amacıyla bilim insanları tarafından farklı konularda yapılan eğitim araştırmalarına yönelik olarak özellikle fen ve matematik branş öğretmenlerinin tutumlarının incelenmesi önem arz etmektedir. Bu anlamda fen ve matematik branş öğretmenlerinin eğitim araştırmalarına yönelik tutumlarının incelendiği bu çalışmanın, alana bu anlamda katkısının olacağı düşünülmektedir.

Araştırmanın amacı: Bu çalışmada, fen ve matematik branş öğretmenlerinin eğitim araştırmalarına yönelik tutumlarının incelenmesi amaçlanmıştır. $\mathrm{Bu}$ amaç doğrultusunda aşağıdaki alt problemlere cevap aranmıştır. 
1) Öğretmenlerin eğitim araştırmalarına yönelik tutumları genel olarak ne düzeydir?

2) Öğretmenlerin eğitim araştırmalarına yönelik tutumları arasında cinsiyetler açısından anlamlı bir farklılık var mıdır?

3) Öğretmenlerin eğitim araştırmalarına yönelik tutumları arasında branşları açısından anlamlı bir farklılık var midır?

\section{Yöntem}

$\mathrm{Bu}$ çalışmada nicel yaklaşımın deneysel olmayan araştırma desenlerinden biri olan karşılaştırma yöntemi kullanılmıştır. Bağımlı ve bağımsız değişkenler arasındaki nedensel ilişkiyi belirlemek amacıyla kullanılan karşılaştırma çalışmalarında, herhangi bir konuya yönelik iki veya daha fazla grubun görüşleri arasında bir farklılık olup olmadığı, ortaya çıan durumun nedenleri, bu nedenleri etkileyen değişkenler ya da etkinin sonuçları belirlenmeye çalışılır (Fraenkel, Wallen \& Hyun, 2012; McMillan ve Schumacher, 2010). Bu çalışmada da fen (biyoloji, fizik, kimya) ve matematik öğretmenlerinin eğitim araştırmalarına yönelik genel tutumları incelenmiş ve cinsiyet ve branş değişkenlerine göre karşılaştırılmıştır.

Örneklem: Araştırmanın örneklemini Erzurum il merkezinde kolay ulaşılabilir örnekleme yöntemi ile belirlenmiş liselerde görev yapan fen (biyoloji, fizik, kimya) ve matematik branş öğretmenleri oluşturmaktadır. Çalışmaya katılan toplam 71 öğretmenin cinsiyet ve branşlarına göre dağılımı Tablo 1'de verilmiştir.

Tablo 1. Öğretmenlerin cinsiyet ve branşlarına göre dağllımı

\begin{tabular}{lccccc}
\hline & Biyoloji & Fizik & Kimya & Matematik & Toplam \\
\hline Bayan & 8 & 6 & 8 & 13 & 35 \\
\hline Erkek & 8 & 9 & 6 & 13 & 36 \\
\hline Toplam & 16 & 15 & 14 & 26 & 71 \\
\hline
\end{tabular}


Veri Toplama Aracı ve Verilerin Analizi: Çalışmada veri toplamak amacıyla İlhan ve diğer. (2013) tarafından geliştirilen Likert tipi “Eğitim Araştırmalarına Yönelik Öğretmen Tutum Ölçeği (ЕAÖTÖ)”nden yararlanılmıştır. EAÖTÖ 5'li Likert tipi formatında, öğretmenlerin tutum ifadelerine katılma dereceleri ise, "Hiç Katılmıyorum (1), Katılmıyorum (2), Kararsızım (3), Katılıyorum (4), Tamamen katılıyorum (5) şeklinde oluşturulmuş olup negatif anlamlı ifadeler ters kodlanmıştır. Ayrıca söz konusu ölçek 3 faktörlü yapıda (Eğitim Araştırmalarının Gerekliliği [EAG]), Eğitim Araştırmalarına Değer Verme [EADV], Eğitim Araştırmalarının Uygulanabilirliği [EAU]) 20 maddeden oluşturulmuş olup, güvenirlik katsayısı Cronbach's Alpha 0.88 olarak hesaplanmıştır.

Araştırma verilerinin analizinde SPSS 18.0 istatistik programı kullanılmıştır. Öğretmenlerin tutumlarının değerlendirilmesinde ölçeğin alt boyutları dikkate alınarak puan ortalamaları hesaplanmış ve analizler yapılmıştır. Aritmetik ortalamalar yorumlanırken 1.00-1.80 arasındaki değerler "çok düşük”, 1.81-2.60 arasındaki değerlerin “düşük”, 2.61-3.40 arasındaki değerlerin "orta", 3.41-4.20 arasındaki değerler "yüksek" ve 4.21-5.00 arasındaki değerler "çok yüksek" derecesinde gerçekleştiği kabul edilmiştir (Kutu ve Sözbilir, 2011). Çalışmada aritmetik ortalamaların yanı sıra öğretmenlerin tutumlarının cinsiyet ve branşlarına göre farklılık gösterip göstermediğini test etmek amacıyla tek yönlü MANOVA (çok değişkenli varyans analizi) analizinden yararlanılmıştır. Bilindiği gibi MANOVA, birden fazla bağımlı değişkenin bulunduğu araştırmalarda varyans analizi yapmak için kullanılan bir tekniktir. Analiz öncesinde örneklemin normalliği, varyansların homojen dağılımı vb MANOVA'nın varsayımları test edilmiş ve verilerin MANOVA yapmaya uygun olduğu görülmüştür. Buna göre çalışmanın bağımsız değişkenlerini öğretmenlerin cinsiyet ve branşları oluştururken; bağımlı değişkenlerini 
ise "Eğitim Araştırmalarına Yönelik Öğretmen Tutum Ölçeği” nin üç alt faktörü oluşturmaktadır.

\section{Bulgular}

Çalışmada elde edilen bulgular çalışmanın alt problemleri doğrultusunda sırasıyla incelenmiştir. Buna göre;

Birinci alt probleme ait bulgular: Çalışmanın birinci alt problemi öğretmenlerin eğitim araştırmalarına yönelik genel tutumlarını incelemeyi amaçlamaktadır. Buna göre öğretmenlerin genel olarak eğitim araştırmalarına yönelik tutumlarına ait puanları incelenmiştir (Tablo 2).

Tablo 2. Öğretmenlerin ĕgitim araştırmalarına yönelik genel tutumları

\begin{tabular}{lcc}
\hline MADDELER & $\bar{X}$ & SS \\
\hline Eğitim Araştırmalarının Gerekliliği (EAG) & $\mathbf{4 . 1 8}$ & $\mathbf{0 . 5 1}$ \\
Eğitim araştırmaları derslerde kullanabileceğim yararlı bilgiler sağlar. & 4.41 & 0.58 \\
Eğitim araştırmaları ile ilgili seminerlerden hoşlanırım. & 4.11 & 0.79 \\
Yapılan eğitim araştırmaları öğretim programlarının geliştirilmesi yenilenmesine & 4.34 & 0.61 \\
katkı sağlar. & & \\
Öğretim sürecinde konuya göre öğretim model, yöntem ve teknik seçiminde & 4.21 & 0.67 \\
eğitim araştırma bulguları benim için önemli bir yere sahiptir. & & \\
Yapılan eğitim araştırmaları öğretimde karşışı̆̆ı̆ım problemlere çözüm üretir. & 3.86 & 0.96 \\
Seminerlerde anlatılan eğitim ile ilgili araştırma bulguları fayda sağlar. & 4.07 & 0.82 \\
Eğitim araştırma bulgularına göre sınıfta ders işlemek bana zevk verir. & 4.24 & 0.78 \\
\hline Eğitim Araştırmalarına Değer Verme (EADV) & $\mathbf{4 . 3 9}$ & $\mathbf{0 . 4 1}$ \\
Öğretmenler eğitim araştırma bulgularından yararlanmalıdırlar. & 4.45 & 0.53 \\
Eğitim araştırmalarından haberdar olmak önemlidir. & 4.45 & 0.53 \\
Nitelikli bir öğretmen olmak için eğitim araştırmalarından yararlanmak gerekir. & 4.34 & 0.63 \\
Eğitim ile ilgili bilimsel araştırmaların yapıllması gereklidir. & 4.42 & 0.60 \\
Eğitim araştırmaları öğretmenlik mesleğinin gelişimine katkı sağlar & 4.35 & 0.66 \\
Eğitim ile ilgili bilimsel yayınlar (tez, makale, kitap vb.) eğitimin kalitesinin & 4.35 & 0.59 \\
artmasına katkı sağlar. & & \\
\hline Eğitim Araştırmalarının Uygulanabilirliği (EAU) & $\mathbf{2 . 5 2}$ & $\mathbf{0 . 6 4}$ \\
Eğitim araştırmalarından elde edilen verilere göre ders işlediğimde konular & 2.35 & 0.81 \\
yetişmez. & & \\
Akademisyenlerin yaptığı eğitim araştırmaları sadece kendi kariyerlerini & 2.51 & 0.92 \\
yükseltmek amacıla yapılan araştırmalardır. & & \\
Eğitim ile ilgili bilimsel yayınların (tez, makale, kitap vb.) yüzeysel olduğu & 2.37 & 0.83 \\
\hline
\end{tabular}


kanısındayım.

Eğitim araştırmalarının okul ortamında uygulanabilirliği yoktur.

$2.59 \quad 0.95$

Eğitimde yapılan çalışmaların sonuçlarına göre ders işlemek zaman kaybıdır.

$2.58 \quad 1.07$

Yapılan eğitim araştırmalarının uygulanabilir olduğuna inanmıyorum.

$2.63 \quad 1.05$

Eğitim araştırmalarının bulgularına göre ders işlenmesi öğrencilerin başarılarını $2.61 \quad 1.12$ düşürür.

Genel Ortalama

$3.66 \quad 0.33$

Tablo 2 incelendiğinde, öğretmenlerin ölçekteki ifadelere verdikleri cevaplar açısından ölçeğin geneline ait puanlarının ( $\bar{X}=3.66)$ yüksek düzeyde olduğu görülmüştür. Bunun yanında Eğitim Araştırmalarının Gerekliliği (EAG) alt boyutuna ait puanlarının yüksek $(\bar{X}=4.18)$, Eğitim Araştırmalarına Değer Verme (EADV) alt boyutu puanlarının ise çok yüksek $(\bar{X}=4.39)$ olmakla birlikte üçüncü alt boyut olan Eğitim Araştırmalarının Uygulanabilirliği (EAU) boyutuna ait puan ortalamalarının ise düşük ( $\bar{X}=2.52)$ olduğu görülmektedir.

İkinci alt probleme ait bulgular: Çalışmanın ikinci alt problemi öğretmenlerin eğitim araştırmalarına yönelik tutumları arasında cinsiyetler açısından anlamlı bir farklılık olup olmadığını belirlemeyi amaçlamaktadır. $\mathrm{Bu}$ amaçla öncelikle öğretmenlerin eğitim araştırmalarına yönelik tutum puanlarının betimsel analizi yapılmış (Tablo 3), sonrasında ise cinsiyete göre farklılık gösterip göstermediği test edilmiş ve analiz sonuçları aşağıda sunulmuştur (Tablo 4).

Tablo 3'te görüldüğü gibi bayan ve erkeklerin eğitim araştırmalarına yönelik tutum puanları genel olarak yüksek düzeydedir. Bununla beraber bulgular alt boyutlar açısından değerlendirildiğinde; EAG ve EADV boyutlarında bayan ve erkeklerin puanlarının genel olarak 
yüksek/çok yüksek olmakla birlikte EAU boyutunda her iki cinsiyet için de puanların düşük olduğu ortaya çıkmıştır.

Tablo 3. Öğretmenlerin cinsiyete göre puanlarına ait betimsel istatistikler

\begin{tabular}{ccccc}
\hline Alt Boyutlar & Cinsiyet & $\boldsymbol{n}$ & $\bar{X}$ & $\boldsymbol{S S}$ \\
\hline \multirow{2}{*}{ EAG } & Bayan & 35 & 4.09 & 0.53 \\
& Erkek & 36 & 4.26 & 0.49 \\
\hline \multirow{2}{*}{ EADV } & Bayan & 35 & 4.29 & 0.43 \\
& Erkek & 36 & 4.50 & 0.36 \\
\hline \multirow{2}{*}{ EAU } & Bayan & 35 & 2.54 & 0.52 \\
& Erkek & 36 & 2.50 & 0.74 \\
\hline \multirow{2}{*}{ Ölçeğin Geneli } & Bayan & 35 & 3.60 & 0.33 \\
& Erkek & 36 & 3.72 & 0.33 \\
\hline
\end{tabular}

$\bar{X}$ : Aritmetik ortalama SS: Standart sapma

Çalışmada öğretmenlerin eğitim araştırmalarına yönelik tutum puanlarına ait ortalamaların cinsiyet değişkeni açısından farklılık gösterip göstermediğini tek yönlü MANOVA ile analiz edilmiştir. Yapılan MANOVA analizi sonucunda; ölçeğin alt boyutları açısından öğretmenlerin ölçekten elde edilen ortalama puanları arasında istatistiksel olarak anlamlı bir farklılık olmadığı ortaya çıkmıştır [Wilks' Lambda $(\Lambda)=0.928, F=1.739 ; \mathrm{p}>0.05$ ]. Ancak yapılan iki yönlü izleme testine ait analiz sonuçları incelendiğinde, öğretmenlerin EAG ve EAU alt boyutuna ait tutumlarının cinsiyete bağlı olarak farklılaşmamasına ( $>0.05)$ rağmen EADV alt boyutunda cinsiyetler arasında anlamlı bir farklılığın olduğu ( $p>0.05$ ) tespit edilmiştir (Tablo 4).

Tablo 4. Ölçeğin alt boyutlarına ait puanların MANOVA sonuçları

\begin{tabular}{cccccc}
\hline Bağımlı değişken & $K T$ & $S D$ & $K O$ & $F$ & $p$ \\
\hline EAG & 0.526 & 1 & 0.526 & 2.026 & 0.159 \\
EADV & 0.815 & 1 & 0.815 & 5.283 & 0.025 \\
EAU & 0.017 & 1 & 0.017 & 0.041 & 0.840 \\
\hline
\end{tabular}

KT: Kareler toplamı, SD: Serbestlik derecesi, $\quad$ KO: Kareler ortalamas1 
Üçüncü alt probleme ait bulgular: Çalışmanın üçüncü alt problemi öğretmenlerin eğitim araştırmalarına yönelik tutumları arasında branşları açısından anlamlı bir farklılık olup olmadığını belirlemeyi amaçlamaktadır. $\mathrm{Bu}$ amaçla öncelikle öğretmenlerin eğitim araştırmalarına yönelik tutum puanlarının betimsel analizi yapılmış (Tablo 5), sonrasında ise branşlarına göre farklılık gösterip göstermediği test edilmiş ve analiz sonuçları aşağıda sunulmuştur (Tablo 6).

Tablo 5’te görüldüğü gibi bütün branşlardaki öğretmenlerin eğitim araştırmalarına yönelik tutum puanları genel olarak yüksek düzeydedir. Bununla beraber bulgular alt boyutlar açısından değerlendirildiğinde; EAG ve EADV alt boyutlarında tüm branşlardaki öğretmenlerin tutum puanlarının yüksek/çok yüksek olmakla birlikte, EAU boyutunda fizik öğretmenlerinin orta; biyoloji, kimya ve matematik öğretmenlerinin ise düşük düzeyde ortalamaya sahip olduğu ortaya çıkmıştır.

Tablo 5. Öğretmenlerin cinsiyete göre puanlarına ait betimsel istatistikler

\begin{tabular}{ccccc}
\hline Alt Boyutlar & Branş & $n$ & $\bar{X}$ & $S S$ \\
\hline \multirow{4}{*}{ EAG } & Biyoloji & 16 & 4.25 & 0.47 \\
& Fizik & 15 & 4.26 & 0.41 \\
& Kimya & 14 & 4.16 & 0.49 \\
& Matematik & 26 & 4.09 & 0.61 \\
\hline \multirow{5}{*}{ EADV } & Biyoloji & 16 & 4.53 & 0.36 \\
& Fizik & 15 & 4.56 & 0.33 \\
& Kimya & 14 & 4.43 & 0.31 \\
& Matematik & 26 & 4.20 & 0.45 \\
\hline \multirow{5}{*}{ EAU } & Biyoloji & 16 & 2.49 & 0.58 \\
& Fizik & 15 & 2.71 & 0.54 \\
& Kimya & 14 & 2.26 & 0.53 \\
& Matematik & 26 & 2.57 & 0.75 \\
\hline \multirow{5}{*}{ Ölçeğin Geneli } & Biyoloji & 16 & 3.72 & 0.27 \\
& Fizik & 15 & 3.81 & 0.22 \\
& Kimya & 14 & 3.58 & 0.28 \\
& Matematik & 26 & 3.59 & 0.41 \\
\hline
\end{tabular}


$\bar{X}$ : Aritmetik ortalama SS: Standart sapma

Çalışmada öğretmenlerin eğitim araştırmalarına yönelik tutum puanlarına ait ortalamaların branş değişkeni açısından farklılık gösterip göstermediği tek yönlü MANOVA ile analiz edilmiştir. Yapılan MANOVA analizi sonucunda; ölçeğin alt boyutları açısından öğretmenlerin ölçekten elde edilen ortalama puanları arasında istatistiksel olarak anlamlı bir farklılık olmadığı ortaya çıkmıştır [Wilks' Lambda $(\Lambda)=0.792, \mathrm{~F}=1.772 ; \mathrm{p}>0.05$ ]. Ancak yapılan iki yönlü izleme testine ait analiz sonuçları incelendiğinde, öğretmenlerin EAG ve EAU alt boyutuna ait tutumlarının branşlarına bağlı olarak farklılaşmamasına $(\mathrm{p}>0.05)$ rağmen EADV alt boyutunda branşlar arasında anlamlı bir farklılığın olduğu $(\mathrm{p}<0.05)$ tespit edilmiştir (Tablo 6).

Tablo 6. Ölçeğin alt boyutlarına ait puanların MANOVA sonuçları

\begin{tabular}{cccccc}
\hline Bağımlı değişken & $K T$ & $S D$ & $K O$ & $F$ & $p$ \\
\hline EAG & 0.366 & 3 & 0.122 & 0.452 & 0.716 \\
EADV & 1.701 & 3 & 0.567 & 3.894 & 0.013 \\
EAU & 1.617 & 3 & 0.539 & 1.351 & 0.265 \\
\hline
\end{tabular}

KT: Kareler toplamı, SD: Serbestlik derecesi, $\quad$ KO: Kareler ortalaması

\section{Tartışma ve Sonuç}

$\mathrm{Bu}$ çalışmada fen (biyoloji, fizik, kimya) ve matematik öğretmenlerinin eğitim araştırmalarına yönelik tutumlarının Eğitim Araştırmalarına Yönelik Öğretmen Tutum Ölçeği (EAÖTÖ)'ne ait puanları “Eğitim Araştırmalarının Gerekliliği (EAG)”, "Eğitim Araştırmalarına Değer Verme (EADV)" ve "Eğitim Araştırmalarının Uygulanabilirliği (EAU)" başlıklı üç alt boyutu açısından cinsiyet ve branş değişkenlerinden etkilenme dereceleri açısından incelenmiştir.

Çalışmanın bulguları öğretmenlerin genel tutumları açısından incelendiğinde; öğretmenlerin bilimsel araştırmalara yönelik tutumlarının genel olarak yüksek düzeyde olduğu 
ortaya çıkmıştır. Bununla beraber bulgular alt boyutlar açısından incelendiğinde, EAG ve EADV puanlarının yüksek/çok yüksek olduğu tespit edilmiştir. Bu bulgulara göre öğretmenler eğitim araştırmalarının gerekliliğine inanmakta ve değer vermektedirler. Alan yazında yapılan çalışmalarda da benzer bulgulara ulaşılmıştır (Çakmak vd., 2015; Kurt, İzmirli, Fırat ve İzmirli, 2011; Yavuz-Konokman vd., 2013). Örneğin; Polat (2014) eğitim fakültesi öğrencilerinin bilimsel araştırmaya yönelik tutumlarını incelediği çalışmasında Eğitim Fakültesinde öğrenim gören ve farklı anabilim dallarına kayıtlı 417 öğrenciye bir anket uygulamış ve uygulama sonucunda öğrencilerin bilimsel araştırmaya yönelik tutumlarının orta düzeyde olduğunu belirlemiştir. Diğer taraftan Çakmak ve diğer (2015) tarafından sosyal bilgiler öğretmen adaylarının bilimsel araştırmaya yönelik tutumlarının incelendiği çalışmada, öğretmen adaylarının bilimsel araştırmaya yönelik tutumların iyi olduğu tespit edilmiştir. Sonuç olarak alan yazındaki çalışma bulgularıyla paralellik gösteren bu çalışmada, öğretmenlerin eğitim araştırmalarının gerekliliği ve değerli olduğuna yönelik tespit edilen olumlu tutumlar çalışma açısından oldukça sevindiricidir. Zira öğretmenlerin yapılan çalışmaların önemi ve faydasına inanmalarının onlardan daha fazla yararlanmalarını etkileyebileceği söylenebilir (İlhan vd., 2013). Ayrıca, Butt ve Shams (2013)'nn de ifade ettiği gibi bilgi temelli toplumlarda bilimsel araştırmalara yönelik tutumun pozitif olması eğitim sürecinde başarının anahtarıdır. Bu açıdan bakıldığında çalışmada fen ve matematik öğretmenlerinin eğitim araştırmalarına yönelik tutumlarının yüksek düzeyde olması başarının yakalanması adına olumlu bir durum olarak nitelendirilebilir. Bununla beraber çalışmada üçüncü alt boyut için tespit edilen ve öğretmenlerin eğitim araştırmalarının uygulanabilirliği konusundaki olumsuz tutumları oldukça dikkat çekicidir. Bu noktada eğitim araştırmalarını gerekli ve değerli bulan öğretmenler, uygulama 
noktasında eğitim araştırmalarına olumsuz tutum sergilemektedirler. Yapılan bazı çalışmalarda da uygulayıcıların (öğretmen, yönetici, politikacı) çoğunun genel olarak eğitim araştırmalarına yönelik olumsuz bir bakış açısına sahip olduğu, yapılan araştırmaların uygulamada yaşanan problemlere çözüm üretmediğini düşünmektedirler (Biesta, 2007; Everton, Galton, ve Pell, 2000 Gore ve Gitlin, 2004; Hemsley-Brown ve Sharp, 2003; İlhan vd., 2013). Nitekim Sar1 (2006) tarafından yapılan çalışmada, öğretmenlerin de araştırmacıların ortaya koydukları bilgilerin eğitim ortamlarına doyurucu bir şekilde transfer edilmediğini vurguladığına yönelik elde edilen bulgular bu çalışmanın bulgularını desteklemektedir. Benzer şekilde Ekiz (2006) tarafından yapılan çalışmada da öğretmenlerin eğitim araştırmalarını geleneksel olarak akademisyenlerin yaptıklarını düşünmeleri; ancak kendilerinin de akademisyen araştırmacılar gibi araştırma yapmaları gerektiğine inanmaları bu çalışmanın bulguları ile paralellik göstermektedir. Bütün bu bulgular geleneksel olarak görülen akademik kültür ile uygulama kültürü arasındaki boşluğun varlığını ortaya koymaktadır. Bu noktada alan yazında yapılan çalışmalar uygulamalarını sistematik olarak anlamlaştırma ve geliştirme amacıyla öğretmenlerin de araştırma yapması gerektiğini savunulmaktadır (Ekiz, 2006; Ovens, 2000). Dahası çalışmalar, öğretmenler ile birlikte yürütülen araştırmaların sınıf içerisinde uygulanabilirliğinin oldukça yüksek olduğu iddia edilmektedir (Çepni \& Küçük, 2003; Ekiz, 2006).

Çalışmanın bulguları öğretmenlerin cinsiyetleri açısından incelendiğinde; bayan ve erkek öğretmenlerin eğitim araştırmalarına yönelik tutum puanlarının genel olarak yüksek düzeyde olduğu belirlenmiştir (Tablo 3). Bulgular alt boyutlar açısından değerlendirildiğinde ise EAG ve EADV boyutlarında bayan ve erkeklerin puanlarının genel olarak yüksek/çok yüksek olmakla birlikte EAU boyutunda her iki cinsiyet için de puanların düşük olduğu, ancak üç alt boyutta da 
cinsiyetler arasında anlamlı bir farklılı̆̆ın bulunmadığı tespit edilmiştir. EAU alt boyutu ile ilgili maddeler incelendiğinde, gerek bayan gerekse erkek öğretmenler Ekiz (2006)'in çalışmasında da ulaşılan benzer bulgularda vurgulandığ gibi, zaman ve çeşitli fiziksel olanaklara sahip olmamalarını ve araştırmalara ulaşamamalarını, araştırma yapmalarını engelleyen temel nedenler olarak görmektedirler. Bunun yanında öğretmenler eğitim ile ilgili bilimsel yayınların (tez, makale, kitap vb.) yüzeysel olduğu, aynı zamanda akademisyenlerin yaptığı eğitim araştırmalarının sadece kendi kariyerlerini yükseltmek amacını taşıdığı, okullarda uygulanabilir olmadığı kanısındadırlar. Bu bulgu öğretmenlerin eğitim araştırmalarını yeterince tanımadığı veya takip edemediğini düşündürebilir. Bu konu ile ilgili olarak Sözbilir (2007) ve Yıldırım, İlhan, Şekerci ve Sözbilir (2014) öğretmenlerin eğitim araştırmalarını takip etmeleri, anlama ve uygulamalara yansıtma düzeylerinin geliştirilmesi ile ilgili sorunların üstesinden gelebilmede; öğretmen eğitimi sürecinde öğretmen adaylarının bilimsel araştırmalarla tanışmaları ve küçük çaplı projeler yapmaları, lisansüstü eğitim yapmaları veya hizmet içi eğitimler yoluyla bilimsel araştırma süreci ve sonuçları hakkında bilgilendirilmeleri, araştırmacılarla öğretmenlerin birlikte çalışarak araştırma yapmalarının ciddi bir katkı sunacağını ileri sürmektedir. Öte yandan, bu çalışmanın bulguları alan yazında yapılan çalışmalarla karşılaştırıldığında cinsiyet değişkeni açısından bu çalışmayla örtüşen (Çakmak vd., 2015; Ekiz, 2006; Korkmaz vd., 2011b) veya farklı bulgulara ulaşılan (Korkmaz, Şahin ve Yeşil, 2011a; Polat, 2014) birçok çalışmanın da olduğu görülmektedir. Örneğin eğitim fakültesi öğrencilerinin bilimsel araştırmaya yönelik tutumlarını incelemeyi amaçlayan Polat (2014), araştırma sonunda, öğrencilerin bilimsel araştırmaya yönelik tutumlarının orta düzeyde olduğunu ortaya çıkarmıştır. Bunun yanında araştırmacı katılımcı tutumlarının, genel olarak, cinsiyet, yaş, kayıtlı olunan bölüm, sınıf düzeyi, 
bilimsel araştırmaya yönelik herhangi bir ders alıp almama ve mezun olunan lise türü değişkenlerine göre değişmediğini ancak ölçeğin alt boyutlarında farklılaştığını belirlemiştir. Ayrıca genel anlamda cinsiyet açısından bakıldığında, erkek öğrencilerin kadın katılımcılara oranla bilimsel araştırmalara yönelik daha yüksek düzeyde olumlu tutum sergilemeleri bu çalışmanın bulgularını desteklemektedir.

Çalışmada son olarak öğretmen tutumları branşlarına göre incelendiğinde; ölçeğin alt boyutları açısından öğretmenlerin ölçekten elde edilen ortalama puanları arasında istatistiksel olarak anlamlı bir farklılık olmadığı ortaya çıkmıştır. Ancak yapılan iki yönlü izleme testine ait analiz sonuçları incelendiğinde, öğretmenlerin EAG ve EAU alt boyutuna ait tutumlarının branşlarına bağlı olarak farklılaşmamasına $(\mathrm{p}>0.05)$ rağmen EADV alt boyutunda branşlar arasında anlamlı bir farklılığın olduğu $(\mathrm{p}<0.05)$ tespit edilmiştir (Tablo 6). EADV alt boyutuna ait puanlara bakıldığında bu farklılığın matematik öğretmenlerinin fen grubu öğretmenlerine kıyasla çok daha düşük bir ortalamaya sahip olmasından kaynaklandığı açıktır (Tablo 5). Buna göre matematik öğretmenlerinin fen branş öğretmenlerine göre eğitim araştırmalarına değer verme boyutunda daha az olumlu tutum sergiledikleri anlaşılmaktadır. Alan yazında bu çalışmanın bulgularının aksine Polat (2014) çalışmasında, ilköğretim matematik bölümü öğrencilerinin diğer sözel ağırlıklı branşlardaki öğrencilere göre araştırmacılara yönelik daha pozitif bir tutum içinde oldukları bulgusuna ulaşmıştır. Elbette alan yazında matematik ve fen öğretmenlerinin eğitim araştırmalarına yönelik tutumlarını doğrudan karşıllaştıran bir çalışmaya henüz rastlanmadığı için, bu çalışmada matematik öğretmenlerinin fen branş öğretmenlerinden daha az olumlu tutuma sahip olmalarının nedeni üzerine kesin bir yargıya varmak henüz mümkün değildir. Dolayısıyla branş değiş̧keni açısından öğretmenlerin bilimsel araştırmalara 
yönelik tutumları alan yazındaki araştırmalara göre farklılık arz etmekle birlikte fen ve matematik öğretmenleri arasında genel olarak hangi grubun bu noktada daha çok olumlu tutuma sahip olduğu net değildir.

Bulgular genel olarak değerlendirildiğinde öğretmenler eğitim araştırmalarının önemi, değeri ve bilime katkısı adına olumlu tutuma sahiptirler. Ancak uygulama noktasında tutumları olumsuz yönde değişmektedir. Zira öğretmenler eğitim araştırmalarını zaman kaybı olarak görmekte, okul ve derslerinde uygulama konusunda isteksiz olmakta ve araştırma bulgularının eğitime katkı sağlamayacağını düşünmektedirler. Elbette öğretmenlerin bu olumsuz düşüncelerinin arkasında yatan sebeplerin araştırılması gerekli görülmektedir. Bu konu ile ilgili olarak Korkmaz vd. (2011b) çalışmalarında, özellikle bayan öğretmenlerin bilimsel araştırmaların vakit kaybı olarak görüldüğg̈ için yardımcı olmaya isteksiz olunduğunu belirtirken, erkek öğretmenlerin daha çok, okul idaresi aracılığıyla emrivaki yapılması, verileri yüz yüze değil başkalarının aracılı̆̆ıyla toplanması, yanlış zamanda anket uygulanmaya çalışılması, çok sıkıcı uygulamaların olması, bu tür taleplerin çok sık olması, araştırmacıların kendilerini öğretmenlerden üstün görmeleri, bu tür araştırmaların yalnızca unvan kazanmak için yapıldığı, konunun öneminin ve yapılan işin ciddiyetinin farkında olunmaması veya görüşlerin dikkate alınmadığı gibi düşünceler yüzünden öğretmenlerin yardımcı olmaya isteksiz olduklarını vurgulamaktadır.

Elbette yukarıda ifade edilenlerin yanında öğretmenlerin eğitim araştırmalarını uygulama boyutundaki olumsuz tutumları, onların eğitim araştırması yapma konusundaki yetersizliği ile de ilişkili olabilir. $\mathrm{Bu}$ durum öğretmenlerin lisansüstü eğitim yapmalarının gerekliliğine işaret edebilir. Zira Yıldırım vd (2014) de lisansüstü eğitim yapmanın öğretmenlere araştırmaları takip 
etme açısından önemli bir katkı sağladığını, bu sebeple öğretmenler arasında bilimsel araştırma sürecine katılmayı destekleyen en önemli unsurlardan biri olan lisansüstü eğitimin MEB tarafından teşvik edilmesi gerektiğini ifade etmişlerdir. Nitekim alan yazında benzer bulgulara ulaşılan bazı araştırmalarda da bu konuya dikkat çekilmiştir (Broekkamp \& van Hout-Wolters, 2007; Vanderlinde \& van Braak, 2010). Sonuç olarak araştırmada elde edilen bulgular neticesinde aşağıdaki önerilerde bulunabilir:

İleride yapılacak benzer nitelikli çalışmalarda, fen ve matematik öğretmenlerinin eğitim araştırmalarına yönelik tutumları daha detaylı incelenebilir.

Eğitim araştırmalarına yönelik tutumların incelendiği araştırmalarda bu çalışmada kullanılan cinsiyet ve branş dışında farklı değişkenler de işe koşularak karşılaştırmalar yapılabilir.

Fen ve matematik branş öğretmenlerinin tutumları diğer branşlardaki öğretmenlerin tutumlarıyla da karşılaştırılması genel olarak öğretmen tutumlarını belirleme adına faydalı olabilir.

Eğitim araştırmalarına yönelik öğretmen tutumları uygulama boyutunda daha detaylı bir şekilde ele alınabilir.

Öğretmenlere eğitim araştırması yapma konusunda bilgilendirici ve teşvik edici seminer vb verilebilir.

Özellikle MEB tarafından öğretmenlerin lisansüstü eğitimleri teşvik edilebilir.

\section{Makalenin Bilimdeki Konumu}

Orta Öğretim Fen ve Matematik Alanları Eğitimi 


\section{Makalenin Bilimdeki Özgünlüğ̈̈}

Alan yazında çalışmaların büyük bir çoğunluğunun bilimsel araştırmalara yönelik olduğu ancak eğitim araştırmalarına yönelik oldukça sınırlı çalışmanın yapıldığı görülmektedir. Bunun yanında, söz konusu çalışmalarda seçilen örneklemin genel olarak sözel ağırlıklı bölümlerdeki branş öğretmenleri ile veya genel olarak tüm alanlardaki öğretmenlerle yürütüldüğü, özelde fen ve matematik branş öğretmenlerinin görüşlerine odaklanılmadığı görülmektedir. Bu nedenle bu çalışmanın fen ve matematik alanlarında öğrenim gören öğretmen adaylarının eğitim araştırmalarına yönelik tutumlarını ortaya koyma açısında alan yazına önemli katkı sağlayacağı düşünülmektedir.

\section{Kaynaklar}

Alber, S. R., \& Nelson, J. S. (2002). Putting research in the collabarative hands of teachers and researchers: An alternative to traditional staff development. Rural Special Education Quarterly, 21(2), 25-32.

Aydın, R., Şahin, H. ve Topal, T. (2008). Türkiye'de ilköğretime sınıf öğretmeni yetiştirmede nitelik arayışları. Türkiye Sosyal Araştırmalar Dergisi, 12(2), 120-142.

Babkie, A. M., \& Provost, M. C. (2004). Teachers as researchers. Intervention in School \& Clinic, 39(5), 260-268.

Biçer, N., Bozkırlı, K. Ç., \& Er, O. (2013). Türkçe öğretmeni adaylarının bilimsel araştırmaya yönelik tutumların değerlendirilmesi. Atatürk Üniversitesi Türkiyat Araştırmaları Enstitüsü Dergisi, (50)3, 327-342. 
Biesta, G. (2007). Bridging the gap between educational research and educational practice: The need for critical distance. Educational Research and Evaluation, 13(3), 295-301.

Broekkamp, H.,\& van Hout-Wolters, B. (2007) The gap between educational research and practice: A literature review, symposium, and questionnaire. Educational Research and Evaluation, 13(3), 203 - 220.

Butt, I. H., \& Shams, J. A. (2013). Master in education student attitudes towards research: A comparison between two public sector universities in Punjab. A Research Journal of South Asian Studies, 28(1), 97-105.

Costa, N., Marques, L., ve Kempa, R. (2000). Science teachers' awareness of findings from education research. Research in Science and Technological Education, 18(1), 37-44.

Çakmak, Z., Taşkıran, C., \& Bulut, B. (2015). Sosyal bilgiler öğretmen adaylarının bilimsel araştırmaya yönelik tutumlarının incelenmesi. Adıyaman Üniversitesi Eğitim Bilimleri Dergisi, 5(2), 287-308.

Çepni, S., Küçük, M. ve Gökdere, M. (2002). Hizmet Öncesi Öğretmen Eğitimi Programlarındaki Araştırmalara Yönelik Derslerin İncelenmesi. V. Ulusal Fen Bilimleri ve Matematik Eğitimi Kongresinde Sunulan Sözlü Bildiri, 16-18 Eylül 2002, ODTÜ Kültür ve Kongre Merkezi, Ankara.

Çepni, S. ve Küçük, M. (2003). Eğitim araştırmalarının fen bilgisi öğretmenlerinin uygulamaları üzerindeki etkilerinin belirlenmesi: Bir örnek olay çalışması. Eğitim Araştırmaları, 4(2), 75-84. 
De Jong, O. (2004). Mind your step: Bridging the research-practice gap. Australian Journal of Education in Chemistry, 64, 5-9.

Ekiz, D. (2006). Sınıf öğretmenlerinin eğitim araştırmalarına karşı tutumları. Kuram ve Uygulamada Ë̆itim Bilimleri Dergisi, 6(2), 373-402.

Fraenkel, J., Wallen, N., \& Hyun, H. H. (2012). How to design and evaluate research in education (8th ed.). Boston: McGraw Hill.

Everton, T., Galton, M., \& Pell, T. (2000). Teachers' perspectives on educational research: Knowledge and context. Journal of Education for Teaching, 26(2), 167-182.

Gore, J. M., ve Gitlin, A. D. (2004). [Re]Visioning the academic-teacher divide: Power and knowledge in the educational community. Teachers and Teaching: Theory and practice, 10(1), 35-58.

Güler, T., Akman, B. (2006). 6 yaş çocuklarının bilim ve bilim insanı hakkındaki görüşleri. Hacettepe Üniversitesi Eğitim Fakültesi Dergisi, 31, 55-56.

Hemsley-Brown, J., ve Sharp, C. (2003). The use of research to improve Professional practice: A systematic review of the literature. Oxford Review of Education, 29(4), 449-471.

İlhan, N., Şekerci, A. R., Sözbilir ve Yıldırım, A. (2013). Eğitim araştırmalarına yönelik öğretmen tutum ölçeğinin geliştirilmesi: Geçerlik ve güvenirlik çalışması. Batı Anadolu Eğitim Bilimleri Dergisi, 4(8), 31-56.

Kart, A., Gelbal, S. (2014). Öğretmen adaylarının bilimsel araştırma öz yeterlik algılarının ikili karşılaştırmalı yargılar yöntemiyle belirlenmesi. Eğitimde ve Psikolojide Ölçme ve Değerlendirme Dergisi, 5(1), 12-23. 
Korkmaz, Ö., Şahin, A., \& Yeşil, R. (2011a). Öğretmen adaylarının bilimsel araştırmalara yönelik tutumları. International Online Journal of Educational Sciences, 3(3), 1169-1194.

Korkmaz, Ö., Şahin, A., \& Yeşil, R. (2011b). Öğretmenlerin bilimsel araştırmalara ve araştırmacılara ilişkin düşünceleri. Kuramsal Eğitimbilim, 4(2), 109-127.

Kurt, A. A., İzmirli, Ö. Ş., Fırat, M., \& İzmirli, S. (2011). Bilimsel araştırma yöntemleri dersineilişkin bilgisayar ve öğretim teknolojileri eğitimi bölümü öğrencilerinin görüşlerinin incelenmesi. Dumlupınar Üniversitesi Sosyal Bilimler Dergisi, 30, 19-28.

Kutu, H., \& Sözbilir, M. (2011). Yaşam temelli ARCS öğretim modeliyle 9. sınıf kimya dersi "Hayatımızda Kimya” ünitesinin öğretimi. Ondokuz Mayıs Üniversitesi Eğitim Fakültesi Dergisi, 30(1), 29-62.

Küçük, M. (2002). Hizmetiçi aksiyon araştırması kurs programının fen bilgisi öğretmenlerine uygulanması: bir örnek olay çalışması. Yayınlanmamış Yüksek Lisans Tezi, Trabzon: Karadeniz Teknik Üniversitesi, Fen Bilimleri Enstitüsü.

Küçükoğlu, A., Taşgın, A., Çelik, N. (2014). Öğretmen adaylarının bilimsel araştırma sürecine ilişkin görüşleri üzerine bir inceleme. Türkiye Sosyal Araştırmalar Dergisi, 17(3), 11-24.

Llewellyn, D. (2002). Inquiry Within: Implementing Inquiry- Based Science Standarts. USA: Corwinn Pres, Inc. A Sage Publications Company.

McBee, M. T. (2004) The classroom as a laboratory: An exploration of teacher research. Roeper Review, 27(1), 52-58.

McMillan, J. H., \& Schumacher, S. (2010). Research in education: Evidence-based inquiry (7th Ed.). Newyork, Longman. 
Ovens, P. (2000). Reflective teacher development in primary science. London \& New York: Falmer Press.

Özdamar, K. (2003). Modern bilimsel araştırma yöntemleri. Eskişehir: Kaan Kitapevi.

Özden, M., \& Ergin, B. (2013). Lisansüstü öğrencilerinin bilimsel araştırmalarda uygulanan etik kurallara yönelik düşüncelerinin belirlenmesi. Mustafa Kemal Üniversitesi Sosyal Bilimler Enstitüsü Dergisi, 10(22), 155-169.

Polat, M. (2014). Eğitim fakültesi öğrencilerinin bilimsel araştırmaya yönelik tutumları. Pamukkale Üniversitesi Sosyal Bilimler Enstitüsü Dergisi, 18, 77-90.

Sarı, M. (2006). Araştırmacı öğretmen: Öğretmenlerin bilimsel araştırmaya ilişkin görüşlerinin incelenmesi. Kuram ve Uygulamada Eğitim Bilimleri, 6(3), 847-887.

Sözbilir, M. (2007). First steps in educational research: the views of Turkish chemistry and biology student teachers. European Journal of Teacher Education, 30(1), 41-61.

Vanderlinde, R., \& van Braak, J. (2010). The gap between educational research and practice: Views of teachers, school leaders, intermediaries and researchers. British Educational Research Journal, 36(2), 299-316.

Yaşar, M. (2014). Bilimsel araştırma yöntemleri dersine yönelik tutum ölçeği geliştirme çalışması: Geçerlik ve güvenirlik. Eğitim Bilimleri Araştırma Dergisi, 4(2), 109-129.

Yavuz-Konokman, G., Tanrıseven, I., \& Karasolak, K. (2013). Öğretmen adaylarının eğitim araştırmalarına ilişkin tutumlarının çeşitli değiş̧kenlere göre incelenmesi. Ahi Evran Üniversitesi Kırşehir Ĕgitim Fakültesi Dergisi, 14(1), 141-158. 
Yıldırım, A., İlhan, N., Şekerci, A. R., \& Sözbilir, M. (2014). Fen ve teknoloji öğretmenlerinin eğitim Araştırmalarını takip etme, anlama ve uygulamalarda kullanma düzeyleri: Erzurum ve Erzincan örneği. Kastamonu Ĕ̆itim Dergisi, 22(1), 81-100. 